\title{
Klasyfikacja WHO 2016 chłoniaków z komórek B - ważne zmiany
}

\section{The WHO 2016 classification of B-cell lymphomas - important changes}

\author{
Monika Prochorec-Sobieszek \\ Zakład Diagnostyki Hematologicznej i Transfuzjologicznej, Instytut Hematologii i Transfuzjologii, Warszawa
}

\begin{abstract}
Streszczenie
W zaktualizowanej klasyfikacji Światowej Organizacji Zdrowia (WHO) 2016 chtoniaków z komórek B uwzględniono najnowsze dane dotyczace objawów klinicznych, biologii, patomorfologii, kryteriów diagnostycznych $i$ bardzo intensywnie rozwijajacych się badan genetycznych, gtównie w zakresie juz istniejacych jednostek histoklinicznych. Zwrócono szczególna uwage na wczesne stadia limfoidalnej neoplazji, grupe wysoce agresywnych chtoniaków z komórek B oraz na znaczenie nowych badań genetycznych/molekularnych, szczególnie w kontekście potencjalnego zastosowania $w$ terapiach celowanych. Pojawito sie kilka nowych jednostek ,tymczasowych”. Podobnie jak w poprzednich wydaniach zaktualizowana klasyfikacja WHO 2016 chtoniaków z komórek B jest platforma do kodyfikacji zmieniajacych sie danych, stanowiac wyraz porozumienia miedzy hematopatologami, genetykami i klinicystami w zakresie potencjalnie kontrowersyjnych zagadnien. Jest również podstawa do wytycznych praktycznego postepowania klinicznego.
\end{abstract}

Słowa kluczowe: klasyfikacja WHO 2016, chłoniaki z komórek B

Hematologia 2016; 7, 4: 261-272

\begin{abstract}
The revised 2016 World Health Organization (WHO) classification of B-cell lymphomas includes the latest updates both on clinical, biological, pathomorphological and diagnostic criteria along with rapidly developing genetic studies for existing entities. Special attention was paid to the early events in lymphoid neoplasms, focusing on highly aggressive B-cell lymphomas and the impact of newer cytogenetic/molecular studies; particularly for their potential use in targeted therapies. Several new provisional entities were introduced. As in previous editions, the updated WHO 2016 classification of B-cell lymphomas is a platform, which serves to codify changing observations and represents a consensus between hematopathologists, geneticists and clinicians concerning potentially controversial topics. It is also forms the basis for clinical practice guidelines.
\end{abstract}

Key words: WHO 2016 classification, B-cell lymphomas

Hematologia 2016; 7, 4: 261-272

Adres do korespondencji: Monika Prochorec-Sobieszek, Zakład Diagnostyki Hematologicznej i Transfuzjologicznej, Instytut Hematologii i Transfuzjologii, ul. Indiry Gandhi 14, 02-776 Warszawa, e-mail: monika.prochorec@interia.pl 


\section{Wprowadzenie}

Podstawą wytycznych diagnostycznych chłoniaków $z$ komórek B pozostaje, opisana szczegółowo w monografii, klasyfikacja Światowej Organizacji Zdrowia (WHO, World Health Organization) z 2008 roku [1]. Ze względu na znaczny postęp wiedzy i publikację - w ciągu ostatnich 8 lat - licznych nowych danych dotyczących objawów klinicznych, biologii, kryteriów diagnostycznych, czynników prognostycznych i predykcyjnych związanych $z$ już istniejącymi jednostkami histoklinicznymi w zakresie nowotworów układu chłonnego, zdecydowano się zaktualizować 4. edycję klasyfikacji WHO 2008. Zgodnie $z$ informacjami Redaktorów, klasyfikacja WHO 2016 będzie stanowić raczej aktualizację poprzedniej 4 . edycji niż nową edycję 5 . W klasyfikacji WHO 2016 zostaną utrzymane poprzednie jednostki histokliniczne bez wprowadzania nowych, zdefiniowanych. Kilka „tymczasowych” jednostek zostanie uznanych za zdefiniowane oraz pojawią nieliczne nowe „tymczasowe” jednostki. Podobnie jak poprzednie edycje zaktualizowana klasyfikacja będzie wynikiem współpracy hematopatologów i klinicystów z zachowaniem zintegrowanego podejścia do definicji jednostek histoklinicznych obejmującego obraz kliniczny, morfologię, immunofenotyp i zmiany genetyczne. Dla tych, którzy na bieżąco śledzą literaturę hematoonkologiczną, zmiany nie będą zaskakujące, ponieważ aktualizacje istniejących już jednostek histoklinicznych będą oparte na opublikowanych wcześniej danych. Podobnie jak poprzednie edycje nowa klasyfikacja będzie podstawą do wytycznych praktycznego postępowania klinicznego. Artykuł zawiera przegląd głównych zmian w klasyfikacji WHO 2016 w zakresie chłoniaków $z$ komórek B na podstawie dostępnego piśmiennictwa [2]. Należy pamiętać, że monografia klasyfikacji WHO 2016 jest jeszcze w przygotowaniu i mogą się pojawiać zmiany nieujęte $\mathrm{w}$ poniższym artykule.

\section{Wczesne/graniczne klonalne limfoproliferacje}

Wielostopniowa patogeneza powstawania nowotworów jest dobrze udokumentowana w zakresie części guzów litych, gdzie klasyfikuje się nowotwory łagodne, graniczne i złośliwe. $\mathrm{W}$ patogenezie nowotworów układu chłonnego trudniej uchwytne są zmiany wczesne, wyprzedzające powstanie zdefiniowanych chłoniaków. W nowej klasyfikacji WHO zwrócono uwagę na problem monoklonalnych limfoproliferacji, które wykazują niewielki potencjał do klinicznej i histologicznej progresji [3]. Ostatnie badania, oparte na coraz bardziej dokładnych technikach immunofenotypowych i genetycznych/molekularnych, pozwoliły wyodrębnić wczesne, klonalne limfoproliferacje, które cechują się zaburzeniami immunofenotypowymi i genetycznymi/molekularnymi spotykanymi w zdefiniowanych chłoniakach/białaczkach oraz jednocześnie nie spełniają wszystkich kryteriów diagnostycznych nowotworów. W zakresie chłoniaków $z$ komórek B dotyczy to przewlekłej białaczki limfocytowej/chłoniaka $z$ małych limfocytów (CLL/ /SLL, chronic lymphocytic leukemia/small lymphocytic lymphoma), szpiczaka plazmocytowego (PCM, plasma cell myeloma), chłoniaka grudkowego (FL, follicular lymphoma) i chłoniaka $z$ komórek płaszcza (MCL, mantle cell lymphoma). W wytycznych WHO 2016 sprecyzowano kryteria diagnostyczne i nowe nazewnictwo zmian wczesnych, które obejmują monoklonalną limfocytozę z komórek B (MBL, monoclonal B-cell lymphocytosis), neoplazję grudkową in situ (ISFN, in situ follicular neoplasia), neoplazję z komórek płaszcza in situ (ISMCN, in situ mantle cell neoplasia) i monoklonalną gammapatię o nieokreślonym znaczeniu (MGUS, monoclonal gammopathy of undetermined significance) [2].

Kryteria rozpoznania MBL pozostają bez zmian i obejmują występowanie monoklonalnych limfocytów B o fenotypie CLL, atypowej CLL lub limfocytów B non-CLL CD5(-) w liczbie nie większej niż $5 \times \mathrm{G} / 1$, utrzymującą się ponad 3 miesiące. Jednocześnie nie stwierdza się innych cech chłoniaka/białaczki [2]. Obecnie wydaje się, że prawie wszystkie przypadki CLL/SLL są poprzedzone MBL [4]. W nowej klasyfikacji WHO podkreśla się konieczność odróżnienia low count $\mathrm{MBL}(<0,5 \times$ $\times \mathrm{G} / \mathrm{l})$ od high count MBL $(>0,5 \times \mathrm{G} / \mathrm{l})$. Przyczyną są wskazania do okresowej obserwacji klinicznej chorych $z$ high count MBL spowodowane możliwością progresji [5]. High count MBL ma wiele wspólnych cech fenotypowych i genetycznych/ /molekularnych z CLL w stopniu Rai 0 [6]. Ponadto, rozważa się koncepcję tkankowej formy MBL typu CLL polegającej na braku występowania centrów proliferacyjnych w utkaniu węzłów chłonnych o morfologii CLL [7]. W nowej klasyfikacji zostanie zmieniona nazwa chłoniaka grudkowego in situ na neoplazję grudkową in situ (ISFN), przy niezmienionych kryteriach jednostki. Intencją modyfikacji jest podkreślenie konserwatywnego podejścia do rozpoznawania chłoniaków we wczesnych etapach neoplazji i wynikające $z$ obserwacji niewielkie ryzyko progresji ISFN. Należy pamiętać, że ISFN często jest związana $z$ wcześniej rozpoznanym lub 
jednocześnie występującym FL, co wymaga wnikliwego badania klinicznego u tych chorych [8]. W ISFN obserwuje się mniej nieprawidłowości chromosomalnych niż $\mathrm{w}$ pełni rozwiniętym FL, chociaż już na wstępnym etapie neoplazji mogą występować wtórne zmiany genetyczne towarzyszące rearanżacji $B C L 2$ [9]. $Z$ podobnych powodów nastąpi zmiana nazwy MCL in situ na neoplazję $z$ komórek płaszcza in situ (ISMCN). W przypadku ISMCN występują nieliczne komórki z ekspresją cykliny D1 w wewnętrznej części strefy płaszcza grudek chłonnych tkanki chłonnej. Jest to zmiana incydentalna i może towarzyszyć innym chłoniakom. Występuje rzadziej niż ISFN i, choć może ulegać uogólnieniu, wydaje się, że wiąże się $z$ niewielkim ryzykiem progresji [10]. Typ dwunastniczy chłoniaka grudkowego (DTFL, duodenal-type follicular lymphoma) w nowej klasyfikacji uznano za wariant FL, w odróżnieniu od innych FL przewodu pokarmowego. Typ dwunastniczy chłoniaka grudkowego ma cechy zlokalizowanego FL, ale ma też wiele wspólnych fenotypowych i genetycznych z ISFN, jak również pewne cechy pozwęzłowego chłoniaka strefy brzeżnej typu MALT (extranodal marginal zone lymphoma of mucosa-associated lymphoid tissue, MALT lymphoma) [11].

Istnieje grupa monoklonalnych, indolentnych proliferacji o nieokreślonym znaczeniu, które nie mają swoich odpowiedników wśród zdefiniowanych chłoniaków. Niektóre $z$ nich pochodzą $z$ komórek $T$ i obejmują indolentną chorobę limfoproliferacyjną $\mathrm{z}$ komórek $\mathrm{T}$ przewodu pokarmowego (indolent T-cell lymphoproliferative disorder of the gastrointestinal tract) i pierwotnego skórnego chłoniaka z komórek T CD8+ okolic dystalnych (primary cutaneous acral CD8+T-cell lymphoma). Obecnie są nowymi, „tymczasowymi” jednostkami w klasyfikacji WHO; zazwyczaj pochodzą z klonalnych, cytotoksycznych limfocytów T CD8 + i wydaje się, że wiążą się z niewielkim ryzykiem progresji [12, 13]. Chłoniak skórny, uprzednio opisany w małżowinie usznej, może występować w okolicy głowy i szyi, twarzy jako pojedyncza zmiana. Jelitowa choroba limfoproliferacyjna występuje $\mathrm{w}$ jelicie cienkim w postaci powierzchownych nacieków ograniczonych do błony śluzowej, bez cech naciekania nabłonków i ściany jelita i atypii. Obie zmiany można łatwo pomylić $z$ agresywnymi jelitowymi i skórnymi chłoniakami z komórek naturalnej cytotoksyczności (NK, natural killers) lub T. Typ dziecięcy chłoniaka grudkowego (PTFL, pediatric-type follicular lymphoma) również zalicza się do tej kategorii. Jest to limfoproliferacja $z$ komórek B występująca w węzłach chłonnych głowy i szyi u dzieci oraz młodych dorosłych. Mimo niepokojącego obrazu mikroskopowego $z$ obecnością komórek blastoidnych i wysokim indeksem proliferacyjnym w strukturach grudkowych, PTFL charakteryzuje się niewielkim ryzykiem progresji po chirurgicznym wycięciu zajętych węzłów chłonnych [14]. W nowej klasyfikacji nastąpi zmiana nazwy $z$ dziecięcego FL na typ dziecięcy FL, ponieważ chłoniak ten może występować również u młodych dorosłych, ponadto PTFL będzie zdefiniowaną jednostką histokliniczną.

Właściwe rozpoznanie wczesnych, monoklonalnych limfoproliferacji jest ważne ze względu na konieczność odpowiedniego postępowania klinicznego i unikanie przeleczenia takich chorych.

\section{Chłoniaki z komórek B o powolnym przebiegu}

W klasyfikacji WHO 2016 zostaną udoskonalone kryteria diagnostyczne chłoniaków $z$ małych komórek B. Nie zmienią się kryteria rozpoznania CLL, polegające na występowaniu we krwi obwodowej monoklonalnych limfocytów o fenotypie CLL w liczbie przekraczającej $5 \times \mathrm{G} / 1$. Obecność cytopenii i objawów związanych $z$ chorobą będzie teraz niewystarczająca do rozpoznania CLL $z$ limfocytozą mniejszą niż $5 \times \mathrm{G} / 1$ - konieczne będzie znalezienie choroby zlokalizowanej poza szpikiem [2]. Zwrócono uwagę na histologiczną progresję CLL, określoną mianem fazy akceleracji, która w obrazie mikroskopowym węzłów chłonnych charakteryzuje się dużymi, zlewającymi się centrami proliferacyjnymi i wysokim indeksem proliferacyjnym (Ki67 $>30 \%$ ). Krzywe przeżycia w tych przypadkach nie są tak niekorzystne jak w przypadku zespołu Richtera, ale rokowanie jest gorsze niż w typowej CLL [15]. W badaniach metodą sekwencjonowania nowej generacji (NGS, next-generation sequencing) wykazano występowanie licznych mutacji genowych w CLL. Niemniej jednak mutacje te występują relatywnie rzadko (w 5-15\% przypadków CLL) $i$, podobnie jak zaburzenia chromosomalne, nie mają znaczenia diagnostycznego. Wśród nich zainteresowanie kliniczne budzą mutacje NOTCH1, SF3B1, BIRC3 i TP53, ponieważ są związane z niekorzystnym rokowaniem i niektóre $z$ nich mogą się stać potencjalnymi celami terapeutycznymi [16]. Być może w przyszłości zostaną włączone do rutynowo ocenianego profilu genetycznego $\mathrm{u}$ chorych na CLL. Obecnie ugruntowane znaczenie kliniczne mają mutacje TP53, które wiążą się z opornością na leczenie fludarabiną i gorszym rokowaniem. Mutacje $S F 3 B 1$ częściej są obserwowane 
w przypadkach $z$ delecją 11q22-q23 i mogą być również związane $z$ opornością na leczenie fludarabiną, szybszą progresją choroby i krótszym przeżyciem całkowitym (OS, overall survival).

Jeszcze do niedawna w białaczce włochatokomórkowej (HCL, hairy cell leukemia) nie opisywano specyficznych zmian genetycznych. W ostatnich badaniach wykazano występowanie mutacji $B R A F$ V600E w niemal $100 \%$ przypadków HCL. Białaczkę tę można łatwo zdiagnozować na podstawie morfologii komórek i ich fenotypu, ale obecność mutacji $B R A F \mathrm{~V} 600 \mathrm{E}$ wyklucza rozpoznanie innych chłoniaków $\mathrm{z}$ małych komórek $\mathrm{B}$, które mogą przypominać HCL, szczególnie wariantu HCL (HCLv, HCL variant) $[17,18]$. Mutację $B R A F \mathrm{~V} 600 \mathrm{E}$ diagnozuje się molekularnie metodą sekwencjonowania DNA lub techniką o większej czułości, tj. techniką allelospecyficznej reakcji łańcuchowej polimerazy (PCR, polimerase chain reaction). Ekspresję białka kodowanego przez zmutowany gen $B R A F$ V600E można również ocenić immunohistochemicznie. Ostatnio opisano, że w HCLv i w przypadkach HCL $z$ użyciem IGHV4-34 często występują mutacje aktywujące w $M A P 2 K 1$, który koduje białko MEK1 [19]. Wykazanie obecności mutacji $B R A F$ V600E u chorych na HCL opornych na standardowe leczenie może być wskazaniem do zastosowania leczenia inhibitorami enzymu kodowanego przez mutant genu $B R A F$ V600E. Należy pamiętać, że $\mathrm{u}$ chorych po leczeniu inhibitorami BRAF $(V-R A F$ murine sarcoma viral oncogene homolog B1) i MEK (mitogen-activated protein kinase) mogą wystąpić zmiany w morfologii i fenotypie komórek HCL, które obejmują utratę wypustek cytoplazmatycznych oraz utratę ekspresji antygenów, takich jak CD25, TRAP i cyklina D1, co ma znaczenie przy dalszym monitorowaniu choroby [20].

Do niedawna uważano, $\dot{z}$ e chłoniak limfoplazmocytowy (LPL, lymphoplasmacytic lympho$m a)$, podobnie jak HCL, nie ma specyficznych nieprawidłowości genetycznych. Obecnie jednak wiadomo, że w około $90 \%$ przypadków LPL/makroglobulinemii Waldenströma można wykazać mutacje MYD88 L265P [21]. Ma to znaczenie w diagnostyce różnicowej, ponieważ LPL wykazuje wiele cech nakładających się $z$ innymi chłoniakami $z$ małych komórek $\mathrm{B} z$ różnicowaniem plazmatycznokomórkowym, szczególnie z MZL, CLL i PCM. Do tej pory LPL rozpoznawano metodą diagnozy z wykluczenia. Chociaż mutacje MYD88 L265P występują w większości przypadków LPL, to nie jest to zmiana genetyczna specyficzna dla LPL, w związku $z$ tym interpretacja tej nieprawidłowości genetycznej powinna być rozpatrywana w kontek- ście pozostałych kryteriów diagnostycznych jednostki. Mutacje MYD88 L265P są często spotykane w monoklonalnej gammapatii o nieokreślonym znaczeniu IgM, którą uważa się za stan prekursorowy dla LPL, oraz $w$ innych chłoniakach $z$ komórek B, między innymi w MZL (ok. 6\%), chłoniaku rozlanym $z$ dużych komórek B (DLBCL, diffuse large $B$-cell lymphoma) $\mathrm{z}$ aktywowanych komórek $\mathrm{B}$ (ABC, activated B-cell) (ok. 30\%) i pierwotnym skórnym DLBCL (ok. 50\%) [22]. Ważny z punktu widzenia diagnostyki różnicowej jest brak mutacji MYD88 L265P w PCM, nawet $z$ obecnością białka monoklonalnego IgM [23]. U około $30 \%$ chorych na LPL występują również mutacje CXCR4 i wydaje się, że zapowiadają bardziej agresywny przebieg kliniczny choroby [24].

Okazało się, że MCL charakteryzuje się większą heterogennością obrazu klinicznego i fenotypu niż wcześniej przypuszczano. Postać klasyczna MCL pochodzi $z$ limfocytów $B$ z niezmutowanym lub minimalnie zmutowanym genem dla $I G H V$ i wykazuje ekspresję SOX11 [25]. Klasyczny MCL jest zlokalizowany głównie w węzłach chłonnych $\mathrm{i}$ innych okolicach pozawęzłowych, a dodatkowe zmiany molekularne/genetyczne prowadzą do rozwoju agresywnych postaci blastoidnych i pleomorficznych. Opisano również wariant białaczkowy, $z$ reguły bez limfadenopatii, natomiast $z$ często występującymi splenomegalią, zajęciem szpiku i krwi obwodowej. W przeciwieństwie do klasycznego MCL wariant ten nie wykazuje ekspresji SOX11, pochodzi z komórek B ze zmutowanym genem $I G H V$ i charakteryzuje się indolentnym przebiegiem klinicznym. W przeszłości takie przypadki często mylono $z$ CLL, dlatego ważna jest wiedza dotycząca występowania wariantu indolentnego MCL. Należy jednak pamiętać, że u chorych $z$ wariantem indolentnym MCL mogą wystąpić wtórne zaburzenia genetyczne, często dotyczące genu TP53 i prowadzące do progresji w bardzo agresywną postać choroby [26]. Większość MCL charakteryzuje się obecnością translokacji t $(11 ; 14)$ (q13;q32) skutkującej powstaniem genu fuzyjnego $I G H-C C N D 1$, co prowadzi do nadekspresji cykliny D1. Zdarza się, że mimo typowych cech morfologicznych i immunofenotypowych dla MCL, obserwuje się brak ekspresji cykliny D1 i rearanżacji IGH-CCND1. Nie wyklucza to rozpoznania MCL, ponieważ około połowa przypadków MCL bez ekspresji cykliny D1 ma rearanżację genu CCND2 [27]. Immunohistochemiczne oznaczenie ekspresji SOX11 jest również pomocne w ustaleniu rozpoznania w rzadko występujących przypadkach MCL bez ekspresji cykliny D1. Należy pamiętać, że 
ekspresja białka cykliny D1, bez związku z translokacją, występuje również w HCL i, choć rzadko, $\mathrm{w}$ innych chłoniakach $\mathrm{z}$ komórek $\mathrm{B}$, takich jak CLL (w centrach proliferacyjnych), i w DLBCL. Natomiast w części przypadków PCM występuje zarówno translokacja CCND1, jak i ekspresja cykliny D1. Poza rearanżacją genów CCND1 i CCND2 w MCL dochodzi do wielu wtórnych zmian genetycznych, takich jak delecja 9p21 (CDKN2A), mutacje punktowe lub delecja $R B 1$ albo TP53 oraz delecja $A T M$. Mutacje NOTCH1 i NOTCH2 występują w mniej niż 15\% przypadków i mają niekorzystne znaczenie prognostyczne; mogą stanowić potencjalny cel terapeutyczny [28].

Klasyfikacja FL na podstawie analizy stopniowania cytologicznego (G1-2, G3) nie uległa zmianie. Chłoniak grudkowy jest nowotworem charakteryzującym się obecnością translokacji $\mathrm{t}(14 ; 18)(\mathrm{q} 32 ; \mathrm{q} 21)$, prowadzącej do nadekspresji białka BCL2, która może być również w części przypadków wynikiem duplikacji i amplifikacji. Translokacja $\mathrm{t}(14 ; 18)(\mathrm{q} 32 ; \mathrm{q} 21)$ jest wykrywana u około $80 \%$ chorych na FL i częstość jej występowania maleje wraz ze zwiększaniem się stopnia cytologicznego. W nowej klasyfikacji zwrócono uwagę na różne warianty FL bez translokacji $\mathrm{t}(14 ; 18)$, takie jak FL o konwencjonalnej morfologii, wariant rozlany $z$ delecją $1 \mathrm{p} 36$ i pierwotny pozawęzłowy FL, na przykład skórny [2]. Wariant rozlany $z$ delecją $1 \mathrm{p} 36$ cechuje się dobrym rokowaniem i ma charakterystyczny obraz kliniczny $z$ dużą, zlokalizowaną masą węzłową w okolicy pachwiny [29]. Opisano też inny wariant FL bez rearanżacji $B C L 2$, ale $z$ silną ekspresja IRF4/MUM1 i translokacją $I G / I R F 4$, który uznano za nową, ,tymczasową" jednostkę histokliniczną w klasyfikacji WHO 2016. Występuje u dzieci i młodych dorosłych w postaci zlokalizowanej w pierścieniu Waldeyera i węzłach chłonnych głowy i szyi. Morfologicznie przypomina FL G3B lub DLBCL. Wykazuje fenotyp komórek pochodzących $z$ ośrodków rozmnażania (GCB, germinal center B-cell) (CD10+/BCL6+), ekspresję BCL2 i BCL6 oraz często rearanżację $B C L 6$. Ponadto obserwuje się silną ekspresję IRF4/ MUM1 i rearanżację IG/IRF4. Wymaga leczenia i cechuje się dobrym rokowaniem. Diagnostyka różnicowa obejmuje typ dziecięcy FL, inne DLBCL oraz FL G3B IRF4/MUM1+ u osób starszych [30]. Pojawiły się również nowe informacje dotyczące heterogenności genetycznej FL. Rearanżacja $I G H /$ $B C L 2$ jest uważana na pierwotną zmianę genetyczną w FL. Obecnie więcej wiadomo na temat stanu wtórnych mutacji mających znaczenie w patogenezie i progresji FL. Mutacje genów związanych $z$ regulacją epigenetyczną, takich jak EZH2, KMT2D (MLL2) i CREBBP, często występują we wczesnych etapach patogenezy FL i mogą być potencjalnymi celami terapeutycznymi. Najprawdopodobniej w przyszłości analiza profilu mutacji będzie elementem rokowniczym i wskazaniem do zastosowaniu nowoczesnego leczenia [31, 32]. Znaczenie diagnostyczne, prognostyczne i terapeutyczne mogą mieć również mutacje $B C L 2$.

\section{Agresywne chłoniaki z komórek B i chłoniaki ,szarej strefy”}

Trudności diagnostyczne dotyczące DLBCL dotyczą najczęściej tak zwanych chłoniaków szarej strefy, które wykazują morfologiczne, immunofenotypowe i genetyczne cechy pośrednie między DLBCL a innymi typami chłoniaków. Badania ostatnich lat przyniosły wyjaśnienie części mechanizmów patogenetycznych $\mathrm{w}$ tych chorobach, co będzie miało wpływ na klasyfikację oraz postępowanie diagnostyczne i terapeutyczne.

Chłoniak z komórek B, nieklasyfikowalny, $z$ cechami pośrednimi między chłoniakiem rozlanym $z$ dużych komórek $B$ a chłoniakiem Burkitta (BCLU, DLBCL/BL, B-cell lymphoma, unclassifiable, with features intermediate between diffuse large B-cell lymphoma and Burkitt lymphoma) był jednostką utworzoną w klasyfikacji WHO 2008, obejmującą grupę chłoniaków o bardzo agresywnym przebiegu klinicznym. Ze względu na niejednoznaczne kryteria diagnostyczne klasyfikacja tej jednostki była do tej pory niekonsekwentna. Okazało się, że wiele chłoniaków tej kategorii cechuje rearanżacja genów $M Y C$ i $B C L 2$ oraz/lub rearanżacja $B C L 6$, tak zwane double/triple hit lymphoma, dlatego dla tych przypadków w nowej klasyfikacji WHO postanowiono utworzyć nową jednostkę - chłoniaka o wysokim stopniu złośliwości $z$ komórek B $\mathrm{z}$ rearanżacją $M Y C$ i BCL2 i/lub BCL6 (high-grade B-cell lymphoma [HGBL], with MYC and BCL2 and/or BCL6 rearrangements) $[2,33]$. Zdefiniowany na podstawie zmian genetycznych HGBL charakteryzuje się różnorodną morfologią komórek (blastoidną, DLBCL, DLBCL/BL, BL), najczęściej fenotypem komórek ośrodków rozmnażania, ekspresją BCL2 oraz wysokim indeksem proliferacyjnym. $Z$ tej kategorii należy wykluczyć chłoniaka limfoblastycznego i FL $z$ rearażacją $M Y C$ i $B C L 2$. Chłoniaki o morfologii blastoidnej lub pośredniej między DLBCL i BL, ale bez rearanżacji $M Y C$ i $B C L 2$ i/lub $B C L 6$, będą ujęte w kategorii chłoniaków o wysokim stopniu złośliwości z komórek B, bliżej nieokreślonych (high-grade B-cell lymphoma, NOS) [34]. Należy 
dodać, że HGBL charakteryzują się bardzo złym rokowaniem i wymagają bardziej intensywnego leczenia niż według schematu R-CHOP (rytuksymab, cyklofosfamid, doksorubicyna, winkrystyna, prednizon), dlatego konieczne jest wyodrębnienie tej jednostki z grupy chłoniaków o agresywnym przebiegu (szczególnie $z$ grupy DLBCL) za pomocą badań genetycznych, na przykład metodą fluorescencyjnej hybrydyzacji in situ (FISH, fluorescent in situ hybridization) [35].

Wytyczne określające zasady wykonywania badań FISH u chorych na agresywne chłoniaki z komórek B nie są dotychczas sprecyzowane. Rozważano możliwość oznaczania rearanżacji $M Y C$, $B C L 2$ i $B C L 6$ we wszystkich DLBCL i HGBL. Koncepcja ta może się jednak okazać trudna do realizacji w praktyce ze względu na stosunkowo dużą grupę docelową i różne możliwości diagnostyczne zakładów patomorfologii zajmujących się diagnostyką chłoniaków. W związku $z$ tym zastanawiano się nad ograniczeniem grupy rekomendowanej do badań na podstawie kryteriów obejmujących morfologię (blastoidna lub o cechach pośrednich między DLBCL/BL) oraz cechy immunofenotypowe (chłoniaki agresywne $z$ fenotypem GCB, indeksem proliferacyjnym $>60 \%$, silną ekspresją BCL2 w > 50\% komórek chłoniaka i ekspresją MYC w > 40\% komórek chłoniaka) [2]. Istnieją też kontrowersje dotyczące postępowania terapeutycznego w chłoniakach double/triple hit, ponieważ nie wszystkie tego typu chłoniaki charakteryzują się agresywnym przebiegiem klinicznym. Nie ma również wytycznych dotyczących zalecanego schematu terapii, chociaż wiadomo, że leczenie zgodnie ze schematem R-CHOP nie wystarcza.

Kolejnym obszarem „szarej strefy” jest dość łagodnie przebiegający chłoniak Hodgkina guzkowy bogaty w limfocyty (NLPHL, nodular lymphocyte predominant Hodgkin lymphoma) i wariant DLBCL — chłoniak z dużych komórek B bogaty w komórki T/histiocyty (T/HRLBCL, T cell/histiocyte-rich large $B$-cell lymphoma) o agresywnym przebiegu klinicznym. Ze względu na podobieństwa morfologiczne i immunofenotypowe istnieją trudności w diagnostyce różnicowej. W nowej klasyfikacji podjęto próbę wyjaśnienia tego problemu. Zwraca się uwagę na warianty histopatologiczne NLPHL $z$ deplecją limfocytów B i przewagą limfocytów T $\mathrm{w}$ podścielisku, ponieważ wiążą się one $\mathrm{z}$ większym zaawansowaniem choroby, większą częstością nawrotów i gorszym rokowaniem, szczególnie $\mathrm{u}$ chorych $\mathrm{z}$ objawami ogólnymi. Jest to niezależny czynnik prognostyczny [36]. Postać rozlana NLPHL bogata $\mathrm{w}$ limfocyty $\mathrm{T}$ oznacza progresję choroby i sugeruje się dla niej nazwę THRLBCL (like transformation of NLPHL). Ostatnie doniesienia wskazują, że pacjenci $z$ gorzej rokującymi wariantami NLPHL lepiej odpowiadają na leczenie stosowane $\mathrm{u}$ chorych na chłoniaki $z$ komórek B (np. R-CHOP) niż na schematy stosowane w HL [37].

Problemy diagnostyczne dotyczą również granicznej kategorii chłoniaków zlokalizowanych w śródpiersiu, obejmujących morfologicznie i immunofenotypowo pierwotnego chłoniaka śródpiersia $z$ dużych komórek B (PMBL, primary mediastinal large B-cell lymphoma) i klasycznego chłoniaka Hodgkina (cHL, classical Hodgkin lymphoma) typu stwardnienia guzkowego. Chociaż w badaniach profilu ekspresji genów wykazano biologiczne podobieństwa między PMBL i cHL, to w większości przypadków można je łatwo zdiagnozować jako oddzielne jednostki histokliniczne. O biologicznych związkach między tymi chłoniakami świadczy fakt występowania utkania obu chłoniaków w jednym guzie śródpiersia. Ponadto zdarza się, że we wznowie wcześniej rozpoznanego cHL występuje utkanie PMBL i odwrotnie. Niekiedy jednak w lokalizacji śródpiersiowej występują chłoniaki wykazujące morfologiczne i immunofenotypowe cechy pośrednie między PMBL i cHL — wtedy są nazywane chłoniakami „szarej strefy”. W obrazie mikroskopowym są widoczne rozlane płaty komórek Hodgkina i Reed-Sternberga o fenotypie CD20+, CD30+, CD15+. W zaktualizowanej klasyfikacji utrzymano jednostkę histokliniczną o cechach pośrednich: chłoniak $z$ komórek $B$, nieklasyfikowany, $z$ cechami pośrednimi między chłoniakiem rozlanym $z$ dużych komórek $B$ a klasycznym chłoniakiem Hodgkina (BCLU, DLBCL/cHL, B-cell lymphoma, unclassifiable, with features intermediate between diffuse large B-cell lymphoma and classical Hodgkin lymphoma). Guzy te występują głównie u młodych mężczyzn i mają bardziej agresywny przebieg niż PMBL i cHL, co powinno wpływać na wybór postępowania terapeutycznego. Nie należy nadużywać tej kategorii i klasyfikować do niej tylko te przypadki, w których odróżnienie cHL i PMBL jest rzeczywiście niemożliwe [38, 39]. W nowej klasyfikacji uznano również „szarą strefę” między NLPHL i cHL bogatym w limfocyty [2].

W zaktualizowanej klasyfikacja WHO zwrócono uwagę na konieczność rozpoznawania podtypów DLBCL podzielonych na podstawie badań profilu ekspresji genów na podtypy GCB i ABC. Oba podtypy różnią się rokowaniem i patogenezą molekularną. W ostatnich badaniach wykazano, że podtyp $\mathrm{ABC}$ - w odróżnieniu od $\mathrm{GCB}$ - jest związany patogenetycznie ze ścieżką czynnika 
jądrowego $\kappa \mathrm{B}(\mathrm{NF} \kappa \mathrm{B}$, nuclear factor $\kappa B)$, co wiąże się $z$ wrażliwością na działanie określonych leków i może oznaczać zmianę schematów leczenia w najbliższej przyszłości [40]. W związku z tym patomorfolodzy będą zobowiązani do stosowania dostępnych algorytmów immunohistochemicznych (np. schemat Hansa oparty na przeciwciałach CD10, BCL6 i IRF4/MUM1) w celu określenia pochodzenia komórkowego DLBCL. Do innych fenotypowych cech mających znaczenie kliniczne w DLBCL, NOS zalicza się koekspresję białek MYC (> 40\% komórek) i BCL2 (> 50\% komórek) występującą u 20-35\% chorych na tego chłoniaka [41]. Większość przypadków nie ma rearanżacji $M Y C$ i $B C L 2$, w związku z czym zaproponowano nazwę double expressors lymphoma. W niektórych badaniach ekspresję MYC/BCL2 uznano za niekorzystny marker prognostyczny dla DLBCL, NOS. Rokowanie nie jest tak niekorzystne jak w HGBL $z$ rearanżacją $M Y C$ i $B C L 2$ i/lub $B C L 6$, dlatego nie utworzono oddzielnej jednostki [42]. Ostatnie badania metodą NGS przyniosły informacje dotyczące stanu mutacji w DLBCL. Geny biorące udział w regulacji epigenetycznej, takie jak $E Z H 2$, $K M T 2 D, C R E B B P$ i EP300, są często zmutowane w DLBCL GCB, podobnie jak w FL. Z kolei DLBCL $\mathrm{ABC}$ często wykazuje nieprawidłowości genetyczne prowadzące do aktywacji ścieżki $\mathrm{NF} \kappa \mathrm{B}$, takie jak: CARD11, CD79A, CD79B, MYD88, TNFAIP3. Mutacje genów, które regulują odpowiedź immunologiczną (CD58, TNFSRF14, B2M) oraz cykl komórkowy i apoptozę (TP53, BCL2), również są często obserwowane u chorych na DLBCL. Wydaje się, że kompleksowa ocena wielu $z$ tych aberracji będzie możliwa w najbliższej przyszłości przy użyciu platform NGS i może prowadzić do bardziej racjonalnych, celowanych terapii u chorych na te chłoniaki [43].

Chłoniak Burkitta (BL, Burkitt lymphoma) jest agresywnym chłoniakiem $z$ komórek B, który wykazuje rearanżację genu $M Y C$ (lokalizacja 8q24) prowadzącą do przeniesienia części kodującej genu $\mathrm{w}$ region promotora jednego $\mathrm{z}$ genów immunoglobulin (IGH/14q32 bądź IGL/22q11 lub $I G K / 2 \mathrm{p} 12)$. W nielicznych przypadkach BL mogą być pozbawione rearanżacji $M Y C$, a regulacja ekspresji MYC odbywa się $\mathrm{w}$ mechanizmie procesów $z$ wiązanych $z \mu$-RNA [44]. Dodatkowo nieprawidłowości chromosomu 11q charakteryzują podtyp bardzo agresywnych chłoniaków $z$ komórek B bez rearanżacji MYC, które przypominają BL. Chłoniak Burkittopodobny $\mathrm{z}$ aberracją $11 \mathrm{q}$ (Burkitt-like lymphoma with 11q aberrations) będzie nową, ,tymczasową" jednostką w zaktualizowanej klasyfikacji
WHO [45]. Dotychczas opublikowano nieliczne opisy przypadków chorych na tego chłoniaka; zaobserwowano $\mathrm{u}$ nich między innymi węzłową prezentację choroby, większy niż w klasycznym BL pleomorfizm komórkowy, bardziej złożony kariotyp i niższy poziom ekspresji białka MYC. Przebieg kliniczny wydaje się podobny do przebiegu klasycznego BL [45]. Należy wziąć pod uwagę tę jednostkę $\mathrm{w}$ diagnostyce różnicowej $z$ HGBL, NOS. Rearanżacja $M Y C$ nie jest specyficzna dla BL i może występować w różnych chłoniakach, takich jak DLBCL, agresywnych chłoniakach $\mathrm{z}$ komórek B double/triple hit, chłoniaku plazmablastycznym, PCM, jak również, choć rzadko, w przypadkach chłoniaków $z$ komórek T [46]. Badania NGS w BL przyniosły nowe dane wyjaśniające patogenezę tego chłoniaka. Stwierdzono mutacje somatyczne obejmujące geny regulujące cykl komórkowy. Inaktywacja TP53, CCND3 i mutacje genów regulujących ścieżkę kinazy 3-fosfatydyloinozytolu (PI3K, phosphatidylinositol 3-kinase), takich jak TCF3 i ID3, występują w około $70 \%$ przypadków BL. Nieprawidłowości CDKN2A i TP53 również są spotykane w BL [44, 47].

W zaktualizowanej klasyfikacji WHO nastąpiły także zmiany dotyczące chłoniaków $z$ dużych komórek B związanych z czynnikami infekcyjnymi. Nastapi zmiana nazwy EBV+ DLBCL wieku podeszłego na chłoniaka rozlanego $z$ dużych komórek B, bliżej nieokreślonego, EBV + (EBV+ DLBCL, NOS, Epstein-Barr virus positive diffuse large B-cell lymphoma, not otherwise specified), ponieważ chłoniak ten może występować również u młodszych chorych. Nie należy kwalifikować do tej grupy innych DLBCL EBV+, jeśli można ustalić bardziej precyzyjne rozpoznanie, na przykład ziarniniakowatość limfoidalną (LyG, lymphomatoid granulomatosis) lub DLBCL związanego z przewlekłym zapaleniem [48]. Wśród chłoniaków z dużych komórek B związanych $z$ infekcją wirusem Epstein-Barr (EBV, Epstein-Barr virus) pojawi się nowa „tymczasowa” jednostka — wrzód śluzówkowo-skórny EBV + (EBV+, mucocutaneous ulcer). Chłoniak ten jest związany $z$ jatrogenną immunosupresją lub ze starzeniem się systemu immunologicznego i mimo niepokojącego obrazu morfologicznego charakteryzuje się stosunkowo lagodnym przebiegiem klinicznym [49]. Kolejną jednostką „tymczasową” będzie bardzo rzadko występujący chłoniak rozlany $z$ dużych komórek B, bliżej nieokreślony, HHV8 + (HHV8+ DLBCL, NOS, human herpesvirus 8 positive diffuse large $B$-cell lymphoma, not otherwise specified). Chłoniak o morfologii immunoblastycznej/plazmablastycznej 
Tabela 1. Ważne zmiany w klasyfikacji Światowej Organizacji Zdrowia (WHO) 2016 chłoniaków z komórek B

Table 1. Important changes in the classification World Health Organization (WHO) of B-cell lymphomas

\begin{tabular}{|c|c|}
\hline Jednostka histokliniczna & Ważne zmiany \\
\hline \multicolumn{2}{|c|}{ Nowotwory z dojrzałych komórek B (mature B-cell neoplasms) } \\
\hline $\begin{array}{l}\text { Przewlekła białaczka limfocytowa/ } \\
\text { /chłoniak z małych limfocytów (CLL/ } \\
\text { /SLL, chronic lymphocytic leukemia/ } \\
\text { /small lymphocytic lymphoma) }\end{array}$ & $\begin{array}{l}\text { - Obecność cytopenii i objawów związanych z chorobą nie wystarcza } \\
\text { do rozpoznania CLL z limfocytozą < } 5 \times \mathrm{G} / \mathrm{l} \text { - konieczne jest znalezienie } \\
\text { choroby zlokalizowanej poza szpikiem } \\
\text { - Histologiczna progresja CLL (faza akceleracji) charakteryzująca się dużymi } \\
\text { centrami proliferacyjnymi i/lub wysokim indeksem proliferacyjnym w centrach } \\
\text { węzłów chłonnych jest niekorzystna rokowniczo } \\
\text { - Określono mutacje o potencjalnym znaczeniu klinicznym, takie jak: TP53, } \\
\text { NOTCH1, SF3B1, ATM, BIRC3 }\end{array}$ \\
\hline $\begin{array}{l}\text { Monoklonalna limfocytoza z komórek B } \\
\text { (MBL, monoclonal B-cell } \\
\text { lymphocytosis)* }\end{array}$ & $\begin{array}{l}\text { - Konieczność odróżnienia MBL low count }(<0,5 \times \mathrm{G} / \mathrm{l}) \text { od high count } \\
(>0,5 \times \mathrm{G} / \mathrm{l}) \text { ze względu na różnice rokownicze } \\
\text { - Koncepcja tkankowej (węzłowej) formy MBL }\end{array}$ \\
\hline $\begin{array}{l}\text { Białaczka włochatokomórkowa } \\
\text { (HCL, hairy cell leukemia) }\end{array}$ & - Mutacje BRAF V600E w większości przypadków \\
\hline $\begin{array}{l}\text { Chłoniak limfoplazmocytowy } \\
\text { (LPL, lymphoplasmacytic lymphoma) }\end{array}$ & $\begin{array}{l}\text { - Występowanie mutacji MYD88 L265P w większości przypadków LPL, } \\
\text { choć nie jest to zmiana genetyczna specyficzna dla LPL }\end{array}$ \\
\hline $\begin{array}{l}\text { Monoklonalna gammapatia } \\
\text { o nieokreślonym znaczeniu, IgM } \\
\text { (MGUS IgM, monoclonal gammopathy } \\
\text { of undetermined significance, IgM)* }\end{array}$ & $\begin{array}{l}\text { - IgM MGUS jest oddzielną jednostką bardziej związaną z LPL i innymi chłoniakami } \\
\text { z komórek B niż ze szpiczakiem plazmocytowym }\end{array}$ \\
\hline $\begin{array}{l}\text { Chłoniak grudkowy (FL, follicular } \\
\text { lymphoma) }\end{array}$ & $\begin{array}{l}\text { - Różne warianty FL bez translokacji t(14;18) } \\
\text { - Lepiej poznany profil mutacji FL, który będzie najprawdopodobniej elementem } \\
\text { rokowniczym i wskazaniem do zastosowania nowoczesnego leczenia }\end{array}$ \\
\hline $\begin{array}{l}\text { Neoplazja grudkowa in situ } \\
\text { (ISFN, in situ follicular neoplasia)* }\end{array}$ & Nowa nazwa FL in situ odzwierciedlająca niewielkie ryzyko progresji \\
\hline $\begin{array}{l}\text { Typ dwunastniczy chłoniaka } \\
\text { grudkowego (DTFL, duodenal-type } \\
\text { follicular lymphoma) }\end{array}$ & Chłoniak zlokalizowany, o niewielkim ryzyku uogólnienia \\
\hline $\begin{array}{l}\text { Typ dziecięcy chłoniaka grudkowego } \\
\text { (PTFL, pediatric-type follicular } \\
\text { lymphoma)* }\end{array}$ & $\begin{array}{l}\text { - Nowa nazwa związana z występowania PTFL, zarówno u dzieci, jak i młodych } \\
\text { dorosłych } \\
\text { - Chłoniak zlokalizowany, o bardzo dobrym rokowaniu, występuje głównie } \\
\text { w okolicy głowy i szyi }\end{array}$ \\
\hline $\begin{array}{l}\text { Głównie rozlany wariant FL z delecją } \\
1 \text { p36 (predominantly diffuse } F L \text { with } \\
1 \text { p36 deletion)* }\end{array}$ & $\begin{array}{l}\text { - Klinicznie - zlokalizowana duża masa węzłowa, często w okolicy pachwiny } \\
\text { - Histopatologicznie - wariant rozlany FL, bez rearanżacji BCL2 i z delecją } 1 \text { p36 }\end{array}$ \\
\hline $\begin{array}{l}\text { Chłoniak z dużych komórek B } \\
\text { z rearanżacją IRF4 (LBCL with IRF4-R, } \\
\text { large } B \text {-cell lymphoma with IRF4 } \\
\text { rearrangement)* }\end{array}$ & $\begin{array}{l}\text { - Nowa jednostka „tymczasowa” wymagająca różnicowania z PTFL i innymi DLBCL } \\
\text { - Chłoniak zlokalizowany, występuje u dzieci i młodych dorosłych w pierścieniu } \\
\text { Waldeyera i węzłach chłonnych głowy i szyi } \\
\text { - Silna ekspresja IRF4/MUM1 i translokacja /G/IRF4 }\end{array}$ \\
\hline $\begin{array}{l}\text { Chłoniak z komórek płaszcza (MCL, } \\
\text { mantle cell lymphoma) }\end{array}$ & $\begin{array}{l}\text { - Koncepcja dwóch podtypów MCL różniących się obrazem histoklinicznym } \\
\text { i patogenezą: } \\
\text { - podtyp konwencjonalny z niezmutowanym lub minimalnie zmutowanym } \\
\text { IGHV i z ekspresją SOX11 w większości przypadków } \\
\text { - podtyp indolentny, głównie ze zmutowanym IGHV i bez ekspresji SOX11, } \\
\text { klinicznie charakteryzujący się białaczką, splenomegalią i brakiem } \\
\text { limfadenopatii; możliwa progresja w postać bardziej agresywną } \\
\text { - Mutacje o potencjalnym znaczeniu klinicznym, takie jak: TP53, NOTCH 1/2, } \\
\text { występują u nielicznych chorych na MCL } \\
\text { - Rearanżacja CCND2 występuje w ok. 50\% przypadków MCL bez ekspresji } \\
\text { cykliny D1 }\end{array}$ \\
\hline $\begin{array}{l}\text { Neoplazja z komórek płaszcza in situ } \\
\text { (ISMCN, in situ mantle cell neoplasia)* }\end{array}$ & Nowa nazwa MCL in situ odzwierciedlająca niewielkie ryzyko progresji \\
\hline
\end{tabular}


Tabela 1 (cd.). Ważne zmiany w klasyfikacji Światowej Organizacji Zdrowia (WHO) 2016 chłoniaków z komórek B

Table 1 (cont.). Important changes in the classification World Health Organization (WHO) of B-cell lymphomas

\begin{tabular}{|c|c|}
\hline Jednostka histokliniczna & Ważne zmiany \\
\hline \multicolumn{2}{|c|}{ Nowotwory z dojrzałych komórek B (mature B-cell neoplasms) } \\
\hline $\begin{array}{l}\text { Chłoniak rozlany z dużych komórek B, } \\
\text { bliżej nieokreślony (DLBCL, NOS, } \\
\text { diffuse large B-cell lymphoma, } \\
\text { not otherwise specified): } \\
\text { - typ z komórek ośrodków } \\
\text { rozmnażania (GCB-type, } \\
\text { germinal center B-cell type)* } \\
\text { typ z aktywowanych komórek B } \\
\text { (ABC-type, activated B-cell type)* }\end{array}$ & $\begin{array}{l}\text { - Wymagane określenie pochodzenia komórkowego (GCB v. ABC) według } \\
\text { dowolnego, akceptowalnego algorytmu oceny immunohistochemicznej, } \\
\text { ze względu na znaczenie prognostyczne i w przyszłości przy wyborze leczenia } \\
\text { - Koekspresję MYC i BCL2 uważa się za nowy niekorzystny marker prognostyczny } \\
\text { (double-expressor lymphoma) } \\
\text { - Lepiej poznany profil mutacji, których znaczenie kliniczne pozostaje do ustalenia }\end{array}$ \\
\hline $\begin{array}{l}\text { Chłoniak rozlany z dużych komórek } \\
\mathrm{B} \text {, bliżej nieokreślony, EBV + (EBV+ } \\
\text { DLBCL, NOS, Epstein Barr virus } \\
\text { positive diffuse large } B \text {-cell } \\
\text { lymphoma, not otherwise specified })^{*}\end{array}$ & $\begin{array}{l}\text { - Zmiana nazwy z EBV+ DLBCL wieku podeszłego, ponieważ chłoniak ten może } \\
\text { występować u młodszych chorych } \\
\text { - Nie należy kwalifikować do tej grupy innych DLBCL z EBV+, jeśli można ustalić } \\
\text { bardziej precyzyjne rozpoznanie }\end{array}$ \\
\hline $\begin{array}{l}\text { Wrzód śluzówkowo-skórny EBV+ } \\
\text { (EBV+ mucocutaneous ulcer)* }\end{array}$ & $\begin{array}{l}\text { - Nowa „tymczasowa” jednostka o stosunkowo łagodnym przebiegu klinicznym, } \\
\text { związana z jatrogenną immunosupresją lub ze starzeniem się systemu } \\
\text { immunologicznego }\end{array}$ \\
\hline $\begin{array}{l}\text { Chłoniak rozlany z dużych komórek B, } \\
\text { bliżej nieokreślony, HHV8+ (HHV8+ } \\
\text { DLBCL, NOS, human herpesvirus } 8 \\
\text { positive diffuse large } B \text {-cell lympho- } \\
\text { ma, not otherwise specified)* }\end{array}$ & $\begin{array}{l}\text { - Nowa „tymczasowa” jednostka związana z wieloogniskową chorobą Castlemana } \\
\text { zlokalizowaną w śledzionie i w węzłach chłonnych } \\
\text { - Występuje u chorych z obniżoną odpornością (HIV+) }\end{array}$ \\
\hline $\begin{array}{l}\text { Chłoniak Burkitta (BL, Burkitt lym- } \\
\text { phoma) }\end{array}$ & - Mutacje ID3 i TCF3 w około 70\% przypadków \\
\hline $\begin{array}{l}\text { Chłoniak Burkittopodobny z aberracją } \\
11 \mathrm{q}(\text { Burkitt-like lymphoma with } 11 q \\
\text { aberration)* }\end{array}$ & $\begin{array}{l}\text { - Nowa „tymczasowa” jednostka, bardzo podobna klinicznie i histopatologicznie } \\
\text { do BL; odrębności obejmują brak rearanżacji MYC oraz inne cechy morfologiczne } \\
\text { i genetyczne }\end{array}$ \\
\hline $\begin{array}{l}\text { Chłoniak o wysokim stopniu złośliwoś- } \\
\text { ci z komórek B z rearanżacjami MYC } \\
\text { i BCL2 i/lub BCL6 (HGBL, MYC-R and } \\
B C L 2-R \text { and/or BCL6-R; high-grade } \\
B \text {-cell lymphoma, with MYC and BCL2 } \\
\text { and/or BCL6 rearrangements)* }\end{array}$ & $\begin{array}{l}\text { - Nowa jednostka o różnorodnej morfologii (blastoidna, DLBCL, DLBCL/BL, BL) } \\
\text { zdefiniowana na podstawie zmian genetycznych typu double-/triple-hit } \\
\text { - Konieczne wykluczenie FL i chłoniaka limfoblastycznego } \\
\text { - Jednostka ta wraz HGBL, NOS zastępuje chłoniaka z komórek B, } \\
\text { nieklasyfikowalnego, z cechami pośrednimi między DLBCL a BL z klasyfikacji } \\
\text { WHO } 2008\end{array}$ \\
\hline $\begin{array}{l}\text { Chłoniak o wysokim stopniu złośliwoś- } \\
\text { ci z komórek B, bliżej nieokreślony } \\
\text { (HGBL, NOS, high-grade B-cell lym- } \\
\text { phoma, NOS)* }\end{array}$ & $\begin{array}{l}\text { Nowa jednostka obejmująca chłoniaki o morfologii blastoidnej lub pośredniej } \\
\text { między DLBCL i BL, ale bez rearanżacji } M Y C \text { i } B C L 2 \text { i/lub } B C L 6\end{array}$ \\
\hline \multicolumn{2}{|c|}{ Chłoniak Hodgkina (HL, Hodgkin lymphoma) } \\
\hline $\begin{array}{l}\text { Chłoniak Hodgkina guzkowy z prze- } \\
\text { wagą limfocytów (NLPHL, nodular } \\
\text { lymphocyte predominant Hodgkin } \\
\text { lymphoma) }\end{array}$ & $\begin{array}{l}\text { - Warianty morfologiczne mają znaczenie rokownicze } \\
\text { - Postacie rozlane bogate w limfocyty T (deplecja limfocytów B) powinny być } \\
\text { określane jako THRLBCL-like transformation of NLPHL }\end{array}$ \\
\hline $\begin{array}{l}\text { Klasyczny chłoniak Hodgkina, postać } \\
\text { bogata w limfocyty (lymphocyte-rich } \\
\text { classical Hodgkin lymphoma) }\end{array}$ & $\begin{array}{l}\text { - Uznana „szara strefa” między NLPHL i klasycznym chłoniakiem Hodgkina } \\
\text { bogatym w limfocyty }\end{array}$ \\
\hline
\end{tabular}

*Zmiany względem klasyfikacji WHO z 2008 r.; jednostki uznane przez WHO Working Group jako „tymczasowe” oznaczono kolorem

wiąże się $z$ wieloogniskową chorobą Castlemana i występuje u chorych $z$ obniżoną odpornością (z obecnością ludzkiego wirusa nabytego niedoboru odporności [HIV +, human immunodeficency virus positive], EBV-) [50].

\section{Podsumowanie}

W zaktualizowanej klasyfikacji WHO 2016 nowotworów układu chłonnego, która najprawdopodobniej ukaże się w postaci monografii w 2017 
Tabela 2. Klasyfikacja chłoniaków z komórek B według Światowej Organizacji Zdrowia (WHO) z 2016 roku

Table 2. Classification of B-cell lymphomas by World Health Organization (WHO) 2016

\begin{tabular}{|c|}
\hline Nowotwory z dojrzałych komórek B (mature B-cell neoplasms) \\
\hline $\begin{array}{l}\text { Chłoniak z komórek B, podtyp nieokreślony (nie spełnia kryteriów żadnej jednostki w klasyfikacji WHO) (B-cell lymphoma, } \\
\text { subtype cannot be determined [not an entitiy within the WHO classification]) }\end{array}$ \\
\hline $\begin{array}{l}\text { Przewlekła białaczka limfocytowa/chłoniak z małych limfocytów (CLL/SLL, chronic lymphocytic leukemia/small lymphocytic } \\
\text { lymphoma) }\end{array}$ \\
\hline Monoklonalna limfocytoza z komórek B (MBL, monoclonal B-cell lymphocytosis)* \\
\hline Białaczka prolimfocytowa z komórek B (B-PLL, B-cell prolymphocytic leukemia) \\
\hline Śledzionowy chłoniak strefy brzeżnej z komórek B (SMZL, splenic B-cell marginal zone lymphoma) \\
\hline Białaczka włochatokomórkowa (HCL, hairy cell leukemia) \\
\hline $\begin{array}{l}\text { Śledzionowy chłoniak/białaczka z komórek B, nieklasyfikowalne (splenic B-cell lymphoma/leukemia, unclassifiable): } \\
\text { • chłoniak rozlany z małych komórek B miazgi czerwonej śledziony (splenic diffuse red pulp small B-cell lymphoma) } \\
\text { - wariant białaczki włochatokomórkowej (HCL-v, hairy cell leukemia-variant) }\end{array}$ \\
\hline $\begin{array}{l}\text { Chłoniak limfoplazmocytowy (LPL, lymphoplasmacytic lymphoma): } \\
\text { - makroglobulinemia Waldenströma (WM, Waldenström macroglobulinemia)* }\end{array}$ \\
\hline $\begin{array}{l}\text { Monoklonalna gammapatia o nieokreślonym znaczeniu, IgM (MGUS IgM, monoclonal gammopathy of undetermined } \\
\text { significance, IgM)* }\end{array}$ \\
\hline Choroba łańcuchów ciężkich $\gamma$ (gamma $H C D$, gamma heavy chain disease) \\
\hline Choroba łańcuchów ciężkich Mu (Mu HCD, mu heavy chain disease) \\
\hline Choroba łańcuchów ciężkich $\alpha$ (alpha HCD, alpha heavy chain disease) \\
\hline $\begin{array}{l}\text { Monoklonalna gammapatia o nieokreślonym znaczeniu, IgG/A (MGUS IgG/A, monoclonal gammopathy of undetermined } \\
\text { significance, } \lg G / A \text { )* }\end{array}$ \\
\hline Szpiczak plazmocytowy (PCM, plasma cell myeloma) \\
\hline Odosobniony plasmocytoma kości (solitary plasmacytoma of bone) \\
\hline Pozakostny plasmocytoma (extraosseous plasmacytoma) \\
\hline Choroby depozytowe monoklonalnych immunoglobulin (MIDD, monoclonal immunoglobulin deposition diseases)* \\
\hline $\begin{array}{l}\text { Pozawęzłowy chłoniak strefy brzeżnej MALT (extranodal marginal zone lymphoma of mucosa-associated lymphoid tissue, } \\
\text { MALT lymphoma) }\end{array}$ \\
\hline $\begin{array}{l}\text { Węzłowy chłoniak strefy brzeżnej (NMZL, nodal marginal zone lymphoma): } \\
\text { - dziecięcy węzłowy chłoniak strefy brzeżnej (pediatric NMZL, pediatric nodal marginal zone lymphoma) }\end{array}$ \\
\hline $\begin{array}{l}\text { Chłoniak grudkowy (FL, follicular lymphoma): } \\
\text { - neoplazja grudkowa in situ (ISFN, in situ follicular neoplasia)* } \\
\text { - typ dwunastniczy chłoniaka grudkowego (DTFL, duodenal-type follicular lymphoma)* }\end{array}$ \\
\hline Typ dziecięcy chłoniaka grudkowego (PTFL, pediatric-type follicular lymphoma)* \\
\hline Chłoniak z dużych komórek B z rearanżacją IRF4 (LBCL with IRF4-R, large B-cell lymphoma with IRF4 rearrangement)* \\
\hline Pierwotny skórny chłoniak z ośrodków rozmnażania (PCFCL, primary cutaneous follicle center lymphoma) \\
\hline $\begin{array}{l}\text { Chłoniak z komórek płaszcza (MCL, mantle cell lymphoma): } \\
\text { - neoplazja z komórek płaszcza in situ (ISMCN, in situ mantle cell neoplasia)* }\end{array}$ \\
\hline $\begin{array}{l}\text { Chłoniak rozlany z dużych komórek B, bliżej nieokreślony (DLBCL, NOS, diffuse large B-cell lymphoma, not otherwise specified): } \\
\text { - typ z komórek ośrodków rozmnażania (GCB-type, germinal center B-cell type)* } \\
\text { - typ z aktywowanych komórek B (ABC-type, activated B-cell type)* }\end{array}$ \\
\hline Chłoniak z dużych komórek B bogaty w komórki T/histiocyty (T/HRLBCL, $T$ cell/histiocyte-rich large B-cell lymphoma) \\
\hline $\begin{array}{l}\text { Pierwotny chłoniak rozlany z dużych komórek ośrodkowego układu nerwowego (primary DLBCL, CNS, primary DLBCL } \\
\text { of the central nervous system) }\end{array}$ \\
\hline $\begin{array}{l}\text { Pierwotny skórny chłoniak rozlany z dużych komórek B typu kończynowego (PCLBCL, leg type, primary cutaneous DLBCL, } \\
\text { leg type) }\end{array}$ \\
\hline $\begin{array}{l}\text { Chłoniak rozlany z dużych komórek B, bliżej nieokreślony, EBV+ (EBV+ DLBCL, NOS, Epstein Barr virus positive diffuse large } \\
\text { B-cell lymphoma, not otherwise specified)* }\end{array}$ \\
\hline Wrzód śluzówkowo-skórny EBV+ (EBV+ mucocutaneous ulcer)* \\
\hline Chłoniak rozlany z dużych komórek B związany z przewlekłym zapaleniem (DLBCL associated with chronic inflammation) \\
\hline Ziarniniakowatość limfoidalna (LyG, lymphomatoid granulomatosis) \\
\hline
\end{tabular}


Tabela 2 (cd.). Klasyfikacja chłoniaków z komórek B według Światowej Organizacji Zdrowia (WHO) z 2016 roku

Table 2 (cont.). Classification of B-cell lymphomas by World Health Organization (WHO) 2016

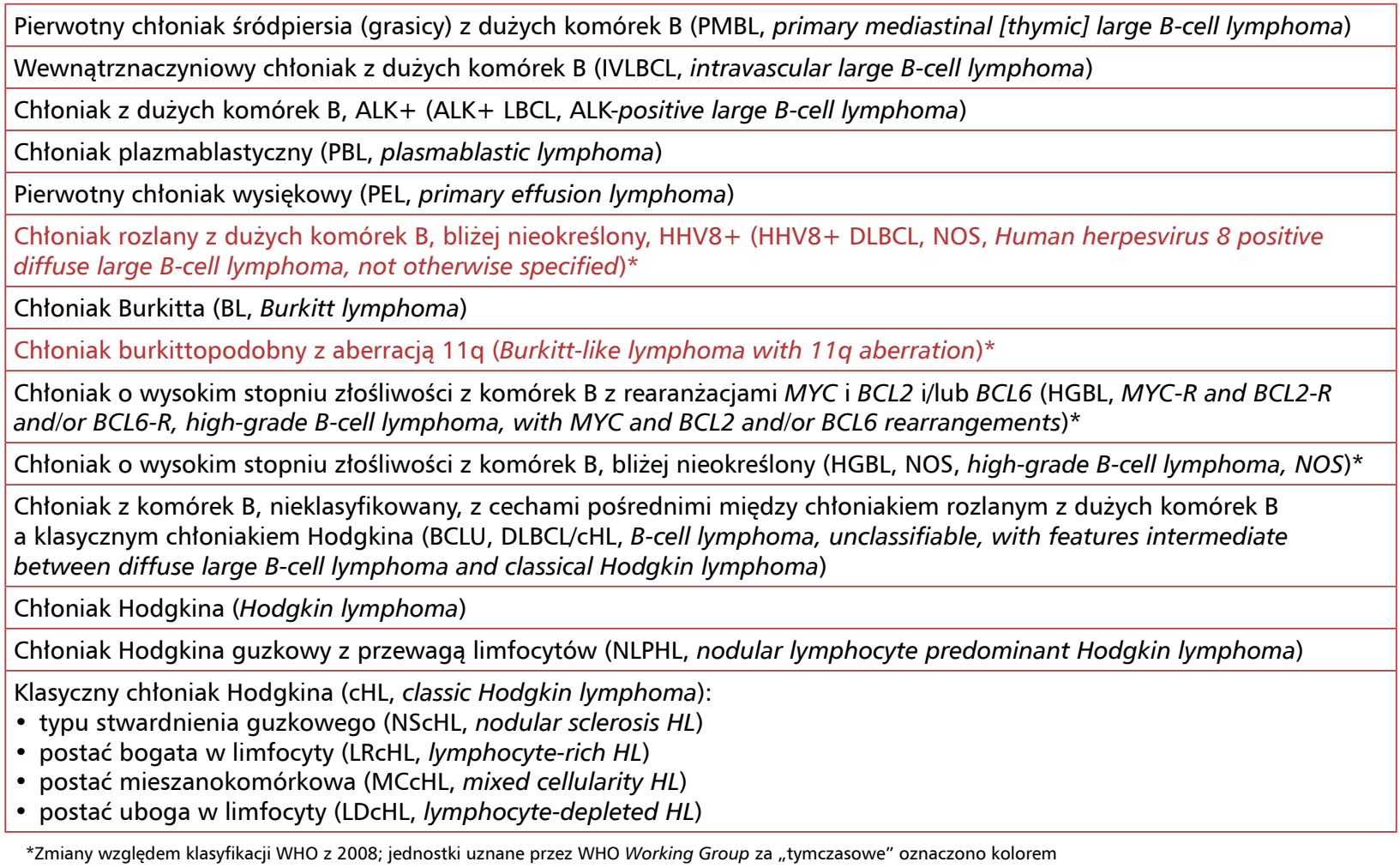

*Zmiany względem klasyfikacji WHO z 2008; jednostki uznane przez WHO Working Group za „tymczasowe” oznaczono kolorem

roku, opisano i uporządkowano najnowsze dane dotyczące objawów klinicznych, biologii, patomorfologii i bardzo intensywnie rozwijających się badań genetycznych nowotworów układu chłonnego w zakresie istniejących już jednostek histoklinicznych (tab. 1, 2). Pojawiło się kilka nowych jednostek „tymczasowych”. Podobnie jak w poprzednich wydaniach $z$ lat 2001 i 2008, zaktualizowana klasyfikacja WHO 2016 jest platformą do kodyfikacji zmieniających się danych, stanowiąc zarówno porozumienie $\mathrm{w}$ odniesieniu do potencjalnie kontrowersyjnych zagadnień, jak i podstawę wytycznych praktycznego postępowania klinicznego.

\section{Piśmiennictwo}

1. Swerdlow S.H., Campo E., Harris N.L.i wsp. WHO classification of tumours of haematopoietic and lymphoid tissues. W: Bosman F.T., Jaffe E.S., Lakhani S.R., Ohgaki H. (red.). World Health Organization classification of tumours. IARC, Lyon 2008.

2. Swerdlow S.H., Campo E., Pileri S.A. i wsp. The 2016 revision of the World Health Organization classification of lymphoid neoplasms. Blood 2016; 127: 2375-2390.

3. Ganapathi K.A., Pittaluga S., Odejide O.O. i wsp. Early lymphoid lesions: conceptual, diagnostic and clinical challenges. Haematologica 2014; 99: 1421-1432.
4. Landgren O., Albitar M., Ma W. i wsp. B-cell clones as early markers for chronic lymphocytic leukemia. N. Engl. J. Med. 2009; 360: 659-667.

5. Vardi A., Dagklis A., Scarfò L. i wsp. Immunogenetics shows that not all MBL are equal: the larger the clone, the more similar to CLL. Blood 2013; 121: 4521-4528.

6. Morabito F., Mosca L., Cutrona G. i wsp. Clinical monoclonal B lymphocytosis versus Rai 0 chronic lymphocytic leukemia: a comparison of cellular, cytogenetic, molecular, and clinical features. Clin. Cancer Res. 2013; 19: 5890-5900.

7. Gibson S.E., Swerdlow S.H., Ferry J.A. i wsp. Reassessment of small lymphocytic lymphoma in the eraof monoclonal B-cell lymphocytosis. Haematologica 2011; 96: 1144-1152.

8. Pillai R.K., Surti U., Swerdlow S.H. Follicular lymphoma-like B cells of uncertain significance (in situ follicular lymphoma) may infrequently progress, but precedes follicular lymphoma, is associated with other overt lymphomas and mimics follicular lymphoma in flow cytometric studies. Haematologica 2013; 98: 1571-1580.

9. Mamessier E., Song J.Y., Eberle F.C. i wsp. Early lesions of follicular lymphoma: a geneticperspective. Haematologica 2014; 99: 481-488.

10. Carvajal-Cuenca A., Sua L.F., Silva N.M. i wsp. In situ mantle cell lymphoma: clinical implications of an incidental finding with indolent clinical behavior. Haematologica 2012; 97: 270-278.

11. Takata K., Tanino M., Ennishi D. i wsp. Duodenal follicular lymphoma: comprehensive gene expression analysis with insights into pathogenesis. Cancer Sci. 2014; 105: 608-615.

12. Perry A.M., Warnke R.A., Hu Q. i wsp. Indolent T-cell lymphoproliferative disease of thegastrointestinal tract. Blood 2013; 122: 3599-3606. 
13. Petrella T., Maubec E., Cornillet-Lefebvre P. i wsp. Indolent CD8-positive lymphoid proliferation of the ear: a distinct primary cutaneous T-cell lymphoma? Am. J. Surg. Pathol. 2007; 31: 1887-1892.

14. Louissaint A. Jr, Ackerman A.M., Dias-Santagata D. i wsp. Pediatric-type nodal follicular lymphoma: an indolent clonal proliferation in children and adults with high proliferation index and no BCL2 rearrangement. Blood 2012; 120: 2395-2404.

15. Giné E., Martinez A., Villamor N. i wsp. Expanded and highly active proliferation centers identify a histological subtype of chronic lymphocytic leukemia ("accelerated" chronic lymphocytic leukemia) with aggressive clinical behavior. Haematologica 2010; 95: 1526-1533.

16. Rossi D., Rasi S., Spina V. i wsp. Integrated mutational and cytogenetic analysis identifies new prognostic subgroups in chronic lymphocytic leukemia. Blood 2013, 121: 1403-1412.

17. Tiacci E., Trifonov V., Schiavoni G. i wsp. BRAF mutations in hairy-cell leukemia. N. Engl. J. Med. 2011; 364: 2305-2315.

18. Xi L., Arons E., Navarro W. i wsp. Both variant and IGHV4-34 expressing hairy cell leukemia lack the BRAF V600E mutation. Blood 2012; 119: 3330-3332.

19. Waterfall J.J., Arons E., Walker R.L. i wsp. High prevalence of MAP2K1 mutations in variant and IGHV4-34 - expressing hairy-cell leukemias. Nat. Genet. 2014; 46: 8-10.

20. Dietrich S., Glimm H., Andrulis M. i wsp. BRAF inhibition in refractory hairy-cell leukemia. N. Engl. J. Med. 2012; 366: 2038-2040 .

21. Treon S.P., Xu L., Yang G. i wsp. MYD88 L265P somatic mutation in Waldenström's macroglobulinemia. N. Engl. J. Med. 2012, 367: 826-833.

22. Jimenez C., Sebastian E., del Carmen Chillon M. i wsp. MYD88 L265P is a marker highly characteristic of, but not restricted to, Waldenström's macroglobulinemia. Leukemia 2013; 27: 1722-1728 .

23. Swerdlow S.H., Kuzu I., Dogan A. i wsp. The many faces of small B cell lymphomas withplasmacytic differentiation and the contribution of MYD88 testing. Virchows Arch. 2016; 468: 259-275.

24. Treon S.P., Cao Y., Xu L. i wsp. Somatic mutations in MYD88 and CXCR4 are determinants of clinical presentation and overall survival in Waldenström macroglobulinemia. Blood 2014; 123: 2791-2796.

25. Jares P., Colomer D., Campo E. Molecular pathogenesis of mantle cell lymphoma. J. Clin. Invest. 2012; 122: 3416-3423.

26. Royo C., Navarro A., Clot G. i wsp. Non-nodal type of mantle cell lymphoma is a specific biological and clinical subgroup of the disease. Leukemia 2012, 26: 1895-1898.

27. Salaverria I., Royo C., Carvajal-Cuenca A. i wsp. CCND2 rearrangements are the most frequent genetic events in cyclin D1mantle cell lymphoma. Blood 2013; 121: 1394-1402.

28. Beà S., Valdés-Mas R., Navarro A. i wsp. Landscape of somatic mutations and clonal evolution in mantle cell lymphoma. Proc. Natl. Acad. Sci. USA 2013; 110: 18250-18255.

29. Katzenberger T., Kalla J., Leich E. i wsp. A distinctive subtype of $\mathrm{t}(14 ; 18)$-negative nodal follicular non-Hodgkin lymphoma characterized by a predominantly diffuse growth pattern and deletions in the chromosomal region 1p36. Blood 2009; 113: 1053-1061.

30. Salaverria I., Philipp C., Oschlies I. i wsp. Molecular Mechanisms in Malignant Lymphomas Network Project of the Deutsche Krebshilfe; German High-Grade Lymphoma Study Group; Berlin-Frankfurt-Münster-NHL Trial Group. Translocations activating IRF4 identify a subtype of germinal center-derived B-cell lymphoma affecting predominantly children and young adults. Blood 2011; 118: 139-147.

31. Pastore A., Jurinovic V., Kridel R. i wsp. Integration of gene mutations in risk prognostication for patients receiving first-line immunochemotherapy for follicular lymphoma: a retrospective analysis of a prospective clinical trial and validation in a population-based registry. Lancet Oncol. 201; 16: 1111-1122.
32. Xerri L., Dirnhofer S., Quintanilla-Martinez L. i wsp. The heterogeneity of follicular lymphomas: from early development to transformation. Virchows Arch. 2016; 468:127-139.

33. Swerdlow S.H. Diagnosis of "double hit" diffuse large B-cell lymphoma and B-cell lymphoma, unclassifiable, with features intermediate between DLBCL and Burkitt lymphoma: when and how, FISH versus IHC. Hematology Am. Soc. Hematol. Educ. Program 2014: 90-99.

34. Kluin P. i wsp. High grade B-cell lymphoma. W: Swerdlow S.H. i wsp. (red.). WHO classification of tumors of hematopoietic and lymphoid tissues. World Health Organization classification of tumours. IARC, Lyon [w druku].

35. Swerdlow S.H. Diagnosis of "double hit" diffuse large B-cell lymphoma and B-cell lymphoma, unclassifiable, with features intermediate between DLBCL and Burkitt lymphoma: when and how, FISH versus IHC. Hematology Am. Soc. Hematol. Educ. Program 2014: 90-99.

36. Hartmann S., Eichenauer D.A., Plütschow A. i wsp. The prognostic impact of variant histology in nodular lymphocyte-predominant Hodgkin lymphoma: a report from the German Hodgkin Study Group (GHSG). Blood 2013; 122: 4246-4252.

37. Xing K.H., Connors J.M., Lai A. i wsp. Advanced-stage nodular lymphocyte predominant Hodgkin lymphoma compared with classical Hodgkin lymphoma: a matched pair outcome analysis. Blood 2014; 123: 3567-3573.

38. Wilson W.H., Pittaluga S., Nicolae A. i wsp. A prospective study of mediastinal gray-zone lymphoma. Blood 2014; 124: 1563-1569.

39. Dunleavy D., Pittaluga S., Grant N. i wsp. Gray zone lymphomas: clinical and histological characteristics and treatment with dose-adjusted EPOCH-R. Blood 2008; 112: 1228.

40. Roschewski M., Staudt L.M., Wilson W.H. Diffuse large B-cell lymphoma-treatment approaches in the molecular era. Nat. Rev. Clin. Oncol. 2014; 11: 12-23.

41. Karube K., Campo E. MYC alterations in diffuse large B-cell lymphomas. Semin. Hematol. 2015; 52: 97-106.

42. Johnson N.A., Slack G.W., Savage K.J. i wsp. Concurrent expression of MYC and BCL2 in diffuse large B-cell lymphoma treated with rituximab plus cyclophosphamide, doxorubicin, vincristine, and prednisone. J. Clin. Oncol. 2012; 30: 3452-3459.

43. Pasqualucci L., Trifonov V., Fabbri G. i wsp. Analysis of the coding genome of diffuse large B-cell lymphoma. Nat. Genet. 2011, 43: 830-837.

44. Love C., Sun Z., Jima D. i wsp. The genetic landscape of mutations in Burkitt lymphoma. Nat. Genet. 201; 44: 1321-1325.

45. Salaverria I., Martin-Guerrero I., Wagener R. i wsp. Molecular Mechanisms in Malignant Lymphoma Network Project; Berlin-Frankfurt-Münster Non-Hodgkin Lymphoma Group. A recurrent 11q aberration pattern characterizes a subset of MYC-negative high-grade B-cell lymphomas resembling Burkitt lymphoma. Blood 2014; 123: 1187-1198.

46. Sewastianik T., Prochorec-Sobieszek M., Chapuy B., Juszczyński P. MYC deregulation in lymphoid tumors: molecular mechanisms, clinical consequences and therapeutic implications. Biochim. Biophys. Acta 2014; 1846: 457-467.

47. Sander S., Calado D.P., Srinivasan L. i wsp. Synergy between PI3K signaling and MYC in Burkitt lymphomagenesis. Cancer Cell 2012; 22: 167-179.

48. Nicolae A., Pittaluga S., Abdullah S. i wsp. EBV-positive large B-cell lymphomas in young patients: a nodal lymphoma with evidence for a tolerogenic immune environment. Blood 2015; 126: 863-872.

49. Dojcinov S.D., Venkataraman G., Raffeld M., Pittaluga S., Jaffe E.S. EBV-positive mucocutaneous ulcer - a study of 26 cases associated with various sources of immunosuppression. Am. J. Surg. Pathol. 2010; 34: 405-417.

50. Dupin N., Diss T.L., Kellam P. i wsp. HHV-8 is associated with a plasmablastic variant of Castleman disease that is linked to HHV-8-positive plasmablastic lymphoma. Blood 2000; 95: 1406-1412. 